\title{
Dempo Paris Peacock Papilio paris dempo Okano, 1988 (Lepidoptera: Papilionidae) Revisited
}

\author{
Muhammad Iqbal $^{1 *}$, Ina Aprilia ${ }^{2}$, Rio Firman Saputra ${ }^{3}$, Pormansyah ${ }^{4}$, Guntur \\ Pragustiandi ${ }^{5}$, Arum Setiawan ${ }^{6}$, Indra Yustian ${ }^{7}$ \\ *e-mail: kpbsos26@yahoo.com \\ ${ }^{1}$ Biology Program, Faculty of Science, Sriwijaya University, Jalan Padang Selasa 524, \\ Palembang, Sumatera Selatan 30129, Indonesia. \\ 2,3,4,5 Conservation Biology Program, Faculty of Science, Sriwijaya University, Jalan \\ Padang Selasa 524, Palembang, Sumatera Selatan 30129, Indonesia. \\ ${ }^{6,7}$ Department of Biology, Faculty of Mathematics \& Natural Sciences, Sriwijaya \\ University. Jl. Raya Palembang-Prabumulih $\mathrm{km} \mathrm{32,} \mathrm{Indralaya,} \mathrm{Indonesia.}$
}

\begin{abstract}
A specimen of Dempo Paris Peacock Papilio paris dempo Okano, 1988 (Lepidoptera: Rhopalocera: Papilionidae) has been caught and collected on 5 February 2020 in lower Dempo mountain, South Sumatra province, Indonesia. This butterfly was preserved for a scientific purpose, and the specimen deposited to biological museum of Department of Biology of Sriwijaya Unversity, with collection number Musbio/En/Coll.02.05022020. After preserved, the specimen was immediately identified using selected references. Recent finding of $P$. paris dempo is a rediscovery for this rare and endemic butterfly in its habitat after 32 years break (1988 to 2020). Based on this specimen, status of $P$. paris dempo is revisited.
\end{abstract}

Keywords: Dempo mountain, endemic, Papilio paris dempo, Rhopalocera, South Sumatra

\section{INTRODUCTION}

The Family Papilionidae or swallow butterflies are medium to large sized butterflies with wing usually black and prominently marked with white or with a bright colour (Holloway et al. 2012). This family contains at least 580 species world wide that occur in Palearctic, Neotropic and Oriental region (Hoskins, 2015). In addition to their beauty and artistic value, these insects have also been central to demonstrates of several aspects of modern biological and ecological theory (Scriber, 1995).

Papilio is one genus of Family Papilionidae (Lewis, 1973; Hoskins, 2015). The genus Papilio are almost group of cosmopolitan butterflies, but mainly tropical ranges throughout all regions of the world, comprises at least 222 species and as the most phenotypically diverse and well-known of all the lepidoptera (Parsons, 1999). Morphologically, Papilio has underwing with the inner margin curved downwards and forming a groove beneath in both sexes (Corbet \& Pendlebury, 1992).

As a second largest island in Indonesia, Sumatra is important island for Papilio. There are approximately 13 to 14 species of genus Papilio in Sumatra (D'Abrera, 1982; Tsukada \& Nishiyama, 1982). Paris peacock Papilio paris is one beautiful butterfly species of genus Papilio. This butterflies has ten subspecies, and two subspecies $P$. paris battacorum and $P$. paris dempo occur in Sumatra. Described as an endemic subspecies restricted in Dempo mountain 
of South Sumatra province in 1988, Dempo Paris Peacock P. paris dempo was a very little known subspecies of butterfly within this genus. In this paper, we revisited status of $P$. paris dempo based on a recent collection from Dempo mountain.

\section{MATERIALS AND METHODS}

On early February 2020, a survey to lower forest of Dempo mountain was carried out. The site is Kampung Empat village, Pagar Alam district, South Sumatra province $\quad\left(4^{\circ} 02^{\prime} 83^{\prime \prime} \mathrm{S}\right.$, $\left.103^{\circ} 08^{\prime} 99^{\prime \prime E}\right)$. During this survey, we caught a swallowtail butterfly on 5 February 2020. This swallowtail butterfly was preserved for a scientific purpose, and the specimen deposited to biological museum of Department of Biology of Sriwijaya Unversity, with collection number of specimen Musbio/En/Coll.02.05022020 (Figure 1 \& 2). After preserved, the specimen was immediately identified using selected references (D'Abrera, 1982; Tsukada \& Nishiyama 1982; Okano, 1988; EkAmnuay, 2012).

\section{RESULTS AND DISCUSSIONS}

The swallowtail butterfly caught at lower forest in Dempo mountain has forewing $51 \mathrm{~mm}$, wingspan $90 \mathrm{~mm}$, upperside of forewing black with mettalic green dusting; underside of forewing black with a series of whitish postdiscal spots and broader in the subapical to apical; upperside of hindwing with a large and brilliant green discal patch in spaces 4-6 not entering the cell, and a red tornal spots with black-centered; underside of hindwing with red spots in termen to tornus (Figure 1 and 2). Following appropriate guides (D'Abrera, 1982; Tsukada \& Nishiyama 1982; Ek-Amnuay, 2012). There are two endemic subspecies of $P$. paris in Sumatra, $P$. paris battacorum Rothschild, 1908 and P. paris dempo Okano, 1988. The P. paris battacorum is distributed in montane zone of northern Sumatra (Rothschild, 1908; Tsukada \& Nishiyama, 1982). Another subspecies, $P$. paris dempo, restricted in Dempo mountain of South Sumatra province (Okano, 1988). Due to the its localities collection and morphological characters described by Okano (1988), the swallowtail butterfly from Dempo mountain is identified as male of $P$. paris dempo.

Okano (1988) describe $P$. paris dempo as here: length forewing of male around $45-51 \mathrm{~mm}$, and female $48 \mathrm{~mm}$; male resembles to subspecies battacorum from North Sumatra and subspecies gedeensis from West Java, but differs from green marking on the hindwing is narrower and longer than those of subspesies battacorum, but wider than subspecies gedeensis (not narrow and long like the subspecies gedeensis); male, the green marking on the hindwing is less bluish than those of subspecies battacorum, but more bluish than those of subspecies gedeensis; female, green marking on the hindwing is smaller and shorter than those of subspecies battacorum and of subspecies gedeensis. The specimens for describing subspecies of $P$. paris dempo are private colletion of Kukimaro Okano, as noted here: Holotype, male, Mount Dempo, MarchJune, 1987; Allotype, female, Mount Dempo, 1985; Paratypes, 8 males, Mount Dempo, March-June, 1987. One paratype was deposited to British Museum. Similar to other subspecies of $P$. Paris in Sumatra and Java, $P$. paris dempo is limited in highland zone, therefore, its distribution is intermittent, occuring in Dempo mountain like in island, a reason why P. paris dempo having distinctive features. Our specimen of $P$. paris dempo collected Dempo mountain has forewing $51 \mathrm{~mm}$ and wingspan $90 \mathrm{~mm}$. This forewing size is still in range of $P$. paris dempo, $45-51 \mathrm{~mm}$. 
No information of wingspan of $P$. paris dempo, and our collection has $90 \mathrm{~mm}$. The subspecies of $P$. paris paris from Thailand has wingspan around 95-110 (EkAmnuay, 2012), suggest $P$. paris dempo is smaller than from $P$. paris paris.

The habitat of $P$. paris dempo as described by Setiawan et al. (2020) for the lower forest of Dempo mountain, a protected forest bordering with tea plantation, at about 1.600 from above sea level which dominated by various of plants, including fig Ficus spp, Clibadium surinamens, pandan Pandanus sp, tree fern Alsophila junghuhniana, stone oak Litsea sp, Lithocarpus sp, schima Schima wallachii and vanda orchid Vanda sp. The host plants known for P. paris are from Family Rutacea, including Citrus spp, Euodia spp (sometimes misspelled as Evodia), Zanthoxylum spp, Euodia lepta, E. lunur-ankenda, E. meliaefolia, E. roxburghiana, Toddalia asiatica, Zanthoxylum armatum, Z. avicennae, $Z$. nitida, $Z$. nitidum and $Z$. valifolium (Tsukada \& Nishiyama, 1982; Robinson et al. 2001; Ek-Amnuay, 2012). In Dempo moutain or adjacent areas, Metusala \& Rindyastuti (2016) listed Euodia latifolia (a synonym of Melicope latifolia) as one plant from Family Rutaceae occur here. It is presumed $E$. latifolia possibly important host plant for $P$. paris dempo.

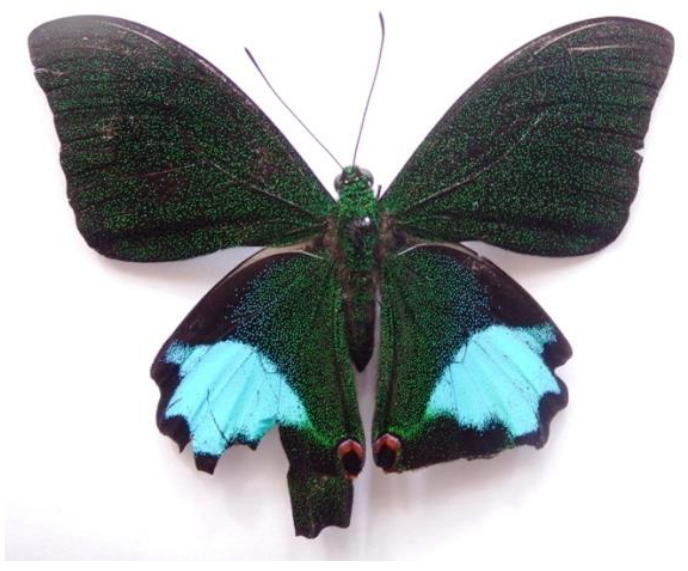

Figure 1. Dorsal view of male $P$. paris dempo collected in Mount Dempo, 5 February 2020 (CMuhammad Iqbal).

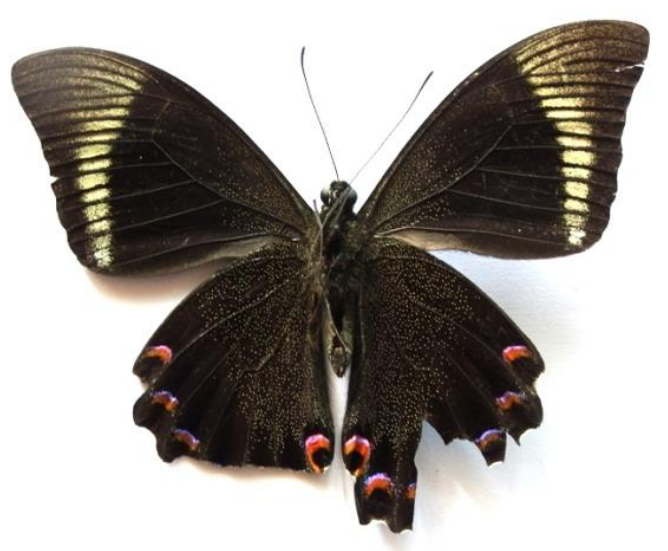

Figure 2. Ventral view of male $P$. paris dempo collected in Mount Dempo, 5 February 2020 (@Muhammad Iqbal).

Since described in 1988 as a new subspecies, record of $P$. paris dempo are none. Our finding of $P$. paris dempo in 5 February 2020 is a rediscovery for this butterfly after 32 years break (1988 to 2020). The $P$. paris dempo has very tiny distribution area, restricted in remaining forest around Dempo mountain. Introduce this beautiful butterfly to local stakeholders is need to support its conservation efforts. Papilio paris is not listed as a threatened butterfly by IUCN (The International Union for Conservation of Nature) redlist criteria because this species has wide range distribution. However, at the subspecies level, P. paris dempo has very small range area, presumed this subspecies become fragile. We propose, in the regional level, the $P$. paris dempo should be protected; and nationally, the status should be listed as Endangered.

\section{CONCLUSIONS}

A recent specimen collection of $P$. paris dempo on 5 February 2020 in Dempo mountain, South Sumatra, is a rediscovery for this butterfly after 32 years break (1988 to 2020). The Euodia latifolia 
is presumed as an important host plant for $P$. paris dempo. It is suggest in the regional level, the $P$. paris dempo should be protected and listed as Endangered species.

\section{Acknowledgements}

First author very grateful to Greenville zoo for providing a grant to visit Dempo mountain and adjacent areas. We thank anonymous reviewers for their constructive comments to earlier version of this manuscript.

\section{REFERENCES}

Corbet, A.S., and Pendlebury, H.M. 1992. The Butterflies of the Malay Peninsula. Fourth Edition. Malayan Nature Society. Kuala Lumpur. Malaysia. 595 pp, plus 69 plates.

D'Abrera, B. 1982. Butterflies of the Oriental region, part I. Hill House Publishers. Victoria. Australia. 244 pp.

Ek-Amnuay, P. 2012. Butterflies of Thailand. Baan Lae Suan Amarin Printing and Publishing.Bangkok. Thailand. 943 pp.

Hoskins, A. 2015. Butterflies of the World. Reed New Holland Publishers Pty Ltd. London. UK. 312 pp.

Holloway, J.D., G. Kibby., and D. Peggie. 2001. The Families of Malesian Moths and Butterflies. Brill. Leiden. Netherland. 455 pp.

Lewis, H.L. 1973. Butterflies of the World. Follett Publishing Company. Chicago. USA. 312 pp.
Metusala, D., dan R. Rindyastuti. 2016. Inventarisasi Jenis Anggrek dan TumbuhanUmum Serta Perbandingan Habitat Hutan Gunung Dempo dan Padiampe, Hutan Lindung Pagar Alam, Sumatera Selatan. Prosiding Seminar Nasional II. 26 Maret 2016. Universitas Muhammadiyah Malang. Malang. 435-449 pp.

Okana, K. 1988. Descriptions of Two New Subspecies of Butterflies from Indonesia and from Thailand (Lep., Rhopalocera). Tokurana. 13(2): 1-.8.

Parsons, M. 1999. The Butterflies of Papua New Guinea, Their systematics and Biology. Academic Press. San Diego. USA. 736 pp, plus 136 plates.

Robinson, G.S., P.R. Ackery, I.J. Kitching, G.W. Beccaloni., and L.M. Hernandez. 2001. Hostplants of the Moth and Butterfly Caterpillars of the Oriental Region. The Natural History Museum. London. UK. 744 pp.

Rothschild, W. 1908. New forms of oriental Papilios. Novitates Zoologicae. 15(1): 165-174.

Scriber, J.M. 1995. Overview of swallowtail butterflies: Taxonomic and distributional latitude. In: Scriber, J.M., Tsubaki, Y. and Lederhouse, R.C. (Eds.), Swallowtail Butterflies: Their Ecology and Evolutionary Biology. Scientific Publishers, Gainesville. Pp, 3-15.

Setiawan, D., I. Aprillia, M. Iqbal, G. Pragustiandi. A. Setiawan., and I. Yustian. 2020. First record of Hagen's batwing Atrophaneura hageni (Rogenhofer, 1889) (Lepidoptera: Papiolinidae) in southern Sumatra, Indonesia. Ecologica Montenegrina. 28: 26-30.

Tsukada, E., and Y. Nishiyama, Y. (1982) Butterflies of the South East Asian 
Dempo Paris Peacock.......Muhammad I., Ina A., Rio F. S., Pormansyah, Guntur P., Arum S., Indra Y.,,...Sainmatika,...Volume 17,...No.1,...Juni 2020,...31-35

islands: $\quad$ Volume I Family

Papilionidae. Plapac Co. Ltd. Tokyo.

Japan. 457 pp. 